\title{
THE SIGNIFICANCE OF PRISON CONDITIONS CASES: BUDGETS AND REGIONS
}

\author{
MALCOLM M. FEELEY
}

\begin{abstract}
This paper examines William Taggart's article on the judicial power of the purse as it affects American prisons and jails. It argues that the central concerns in this area have involved issues of judicial propriety and judicial capacity rather than, as Taggart argues, whether judicially mandated expenditures disrupt normal budget processes. It then takes issue with Taggart's conclusions that the courts have had little impact on prisons and jails. Using his evidence, this paper argues that the courts have had a significant effect in transforming prisons and jails in at least one region of the country, the South.
\end{abstract}

\section{INTRODUCTION}

In "Redefining the Power of the Federal Judiciary," Taggart (1989) is responding to critics of judicial activism who assert that in institutional litigation cases federal courts often usurp the budgetary functions of legislatures. Building on earlier work by Harriman and Straussman (1983), he proposes to enhance the empirical dimension of this debate by exploring the question, "Do judges ... determine budget decisions?" " (quoted in Taggart, 1989, p. 243). He seeks an answer by determining the magnitude of changes in state correctional spending in the aftermath and as a consequence of court orders. Attempting to separate spending increases induced by court orders from other influences, he analyzes whether increases following court orders deviate from models of "normal budgeting" as put forward by various budget theorists. ${ }^{1}$

To this end Taggart examined budget trends for corrections in ten states in which the earliest major prison conditions cases took place. Using a quasi-experimental interrupted time series design to explore "the linkage between court-ordered prison reform and state expenditures for corrections" (ibid., p. 244), he found statisti-

I wish to acknowledge support from the Daniel and Florence Guggenheim Program at the University of California at Berkeley in preparing this paper. It is part of an ongoing study of the impact of court orders on prisons and jails by the author and Edward Rubin that is being supported by the Program.

1 Taggart briefly discusses several alternative budget models as if he intends to compare them in his study. But once raised, he never evaluates them against his data and instead settles on Wildavsky's (1975) model.

LAW \& SOCIETY REVIEW, Volume 23, Number 2 (1989) 
cally significant increases in five states (Alabama, Arkansas, Louisiana, Mississippi, and Oklahoma) and decreases in the other five states (statistically significant in Ohio and nonsignificant in Delaware, Florida, New Hampshire, and Rhode Island). (See his Table 5.) But as Taggart scrutinized these findings more carefully, lagging time between court order and expenditure and distinguishing between capital and operating expenditures, the "significance" of the increases in the five states became problematic: The increases were limited primarily to capital and not to operating expenses.

With this Taggart (ibid., p. 267) concludes that "collectively, court influence on state operating budgets for corrections was almost non-existent." Court-ordered expenditures are obscured within the larger corrections budget. He continues:

Part of the reason the judiciary has not enjoyed greater success in altering state expenditures for corrections can be found in the very nature of state budgeting. Our analysis reveals that spending is shaped in large measure by forces much more compelling and forceful than a single discrete event such as a court order. Consistent with incrementalist expectations, corrections spending was found to be a historical function of previous spending patterns. Scholarly claims to the contrary, the judiciary's ability to overcome these tendencies should not be overestimated. As Wildavsky (1975: 6) reminds us, "the greatest part of any budget is a product of previous decisions." Generally, these are decisions over which the judiciary has little or no control (ibid., p. 268).

\section{THE WRONG QUESTIONS}

Taggart is convincing in his argument that courts have not distorted state budgeting processes, but it is not clear to whom these findings speak. Although in their most polemical moments, some critics of institutional reform litigation assert that judges are profligate spenders who are taking states to the brink of bankruptcy, most serious and sustained critics do not frame their objections in this way (Feeley and Hanson, forthcoming). Their concerns are simply that at times-too many times for their comfort-courts have acted inappropriately by imposing substantial and unwarranted financial obligations on state and local governments. For instance, Harris and Spiller (1976: 111) estimate that the decision in the Arkansas prison case Holt v. Sarver, 300 F. Supp. 825 (E.D. Ark. 1969), increased the state's correctional expenditure six-fold and that the improvements ordered for the Alabama prisons in Pugh v. Locke, 406 F. Supp. 318 (M.D. Ala. 1976), totaled over $\$ 35,000,000$, which represented a two-thirds increase in the state correctional budget (Yarbrough 1987). In his study of the impact of the settlement reached in Guthrie v. Evans, C.A. No. 73-3068 (S.D. Ga. 1979), Chilton (1988: 160) reports that the state spent $\$ 100,000,000$ to renovate the prison at Reidsville, but emphasizes 
that the judge "never expressly ordered that state funds be appropriated for any items except court costs and attorneys' fees."

It is these and other similar figures that critics seize upon when they complain about the "judicial power of the purse." However, their central concerns in citing such figures are not that judges are disrupting "normal budget" models but that the sums involved are substantial. To the critics such expenditures indicate that the courts are heavily involved in the areas of substantive policy making, appropriations, and public administration, functions they believe the courts should not perform. Furthermore, in most of their discussions, the critics do not distinguish budgetary issues from their other, more general concerns about judicial overreach, such as the inability of courts to make polycentric decisions or assess trade-offs and alternatives, the inability of the judiciary to micro-manage complex institutions, and the tendency for presumably limited orders to become sprawling quests for more effective administration. ${ }^{2}$

The objections of these critics are of two types: arguments of propriety and arguments of capacity. Arguments of propriety deal with the proper role of the federal courts and rest upon beliefs about the division of labor of governmental functions. Specific concerns revolve around familiar issues: deference to the democratic processes, appreciation of federalism, and separation of powers. 3 Some have expanded this list, resuscitating the nearly expired Eleventh Amendment, which on its face grants states immunity from suits without their consent but which has been interpreted to allow private suits against state officials.

Frug (1978: 733), one of those critics Taggart is presumably addressing, summarizes the propriety concerns nicely:

... [I]f courts were to have plenary power to define constitutional values, command sufficient appropriations to support those values, and then control by equitable decree the spending of the money appropriated, they would be exercising all power of government-judicial, legislative, and executive.

Although Frug's article is often cited as one of the leading pieces critical of the "judicial power of the purse" and is relied on by Taggart as such, it is instructive to note that the above quote is conditional. Frug is pursuing a formal argument. He does not criticize trial court judges for the amounts they have spent. Rather, he calls for more appellate court review of remedial orders and more guidance-and legislative participation-in structuring costly remedial orders generally. It is the potential for the abuse of the principles of the separation of powers and the values of federalism

2 The best statements of these concerns are found in Fuller ([1957] 1978) and the excellent book by Horowitz (1977).

3 The classic statement on this is by Bickel (1962). See also Frug (1978), Mishkin (1978), Fletcher (1982), Berger (1977), and Glazer (1975; 1978). 
that are his greatest concerns. Although Frug draws on concrete examples of the "judicial power of the purse," he does so not to complain that too much is being spent but to point out that large sums of money are being spent without, in his view, sufficient review. The result, he argues, is a blurring of powers and responsibilities in violation of the system of government envisioned by the framers of the Constitution. As he observes, "such a concentration of power was never contemplated by the Constitution" (ibid.).

This not to say that Frug and others who focus on issues of propriety are unconcerned with fiscal impact, for they certainly are. But when they cite examples of the "judicial power of the purse," they do so to show that the sums involved are far from trivial and that their concerns are real and more than hypothetical. However, nothing in their arguments requires their concerns about the "judicial power of the purse" to be triggered only if court-generated spending exceeds what would have been projected by "normal budget" increases. Indeed, insisting upon an impact in excess of the "normal budget" as a criterion for determining whether courts unduly affect correctional budgets and policy making could be used to enhance their argument, for this might suggest that the courts were affecting priorities within corrections that they did not sufficiently appreciate and that they were illequipped to consider. More generally, such a requirement, if applied to legislatures with the same results, would lead to the conclusion that legislatures do not affect budgets either. But these issues need not be pursued here, since the debate about whether it is proper for courts to affect budgets does not hinge upon their impact on the budget process as a whole.

The second objection to the "judicial power of the purse" is that of capacity. Courts, this argument goes, lack the capacity to make effective policy and to spend money wisely. Horowitz (1977), another critic cited by Taggart, has developed this argument most fully. He complains about the convergence of functions of the separate branches of government and observes:

More openly, self-consciously, and broadly than before, the courts are engaged in efforts to shape or control the behavior of identifiable social groups, groups not necessarily before the court: welfare administrators, employers, school officials, policemen. The expansion of the judicial sphere means that there are more such groups whose behavior has become subject of judicial attention. ... What this means is that there is somewhat less institutional differentiation today than two decades ago. There is now more overlap between the courts and Congress in formulating policy and between the courts and the executive in both formulating and carrying out programs (ibid., pp. 19-20).

Horowitz opposes this trend on the grounds that courts have distinct and limited capacities that in large part are defined by the 
"attributes of adjudication" or the "forms and limits of adjudication" (Fuller, [1957] 1978). Institutional litigation in which courts indirectly appropriate public funds, formulate policies, and then administer them, leads, in his view, to failure. Following Fuller ([1957] 1978), he argues that courts must restrict themselves to what they were designed to do and to what they do best: settle disputes between identifiable parties. ${ }^{4}$

Like Taggart, Horowitz and others who raise similar capacity issues want to bring empirical evidence to bear on the debate. However, Horowitz's concern is not that judicial orders have distorted "normal" budgeting process but that courts have made foolish decisions. The case studies in his Courts and Social Policy (1977) purport to marshal evidence to show that when courts make policy, they make messes, and that when they spend money, they spend it foolishly. Glazer $(1975 ; 1978)$, another critic, has made similar points. Although a finding that court-ordered expenditures grossly distort state budgeting processes could be used to reinforce these conclusions, a contrary finding in no way undercuts them.

In sum I fail to see how Taggart's approach speaks to those critics who are concerned with either judicial propriety or judicial capacity. To join issues with the serious critics of the "judicial power of the purse," it would be necessary to address their central concerns more directly or to show how they have misunderstood the real issues. Taggart's article does neither and thus in my view asks the wrong questions.

\section{THE SIGNIFICANCE OF THE ANSWERS}

Although I have argued that Taggart has not asked the right questions, his answers nevertheless are fascinating for what they reveal about the importance of the courts. In examining them, I have drawn a conclusion at odds with his own. Taggart (1989: 266-267) observes:

The results of this investigation suggest courts have played a limited, if sometimes very significant, role in shaping state expenditures. At a practical level, for those hoping to witness substantial, far-reaching, and enduring effects there is little solace in these findings .... .

I read his findings quite differently. I think they suggest farreaching and enduring effects. Table 7 of his study is instructive in this regard. Three features of this table and the tables on which it is based stand out. First, six of the ten states are Southern. ${ }^{5}$ Second, the states form two groups; in one group expenditures in-

4 Almost all recent discussions of court capacity are informed by Fuller's classic essay "The Forms and Limits of Adjudication" ([1957] 1978), written in 1957 yet, although widely circulated, not published until 1978.

5 Although identified as a border state, Oklahoma, like Texas and some other Western states, has a tradition of prison administration closely linked to the South. See McKelvey (1977: 251-253). 
creased at a statistically significant rate, while in the other group they did not. This difference in movement, I believe, further underscores the significance of the increases. ${ }^{6}$ Third, the increases occurred in Southern states.

These features are important but were overlooked in Taggart's study. I believe that it is important that those states that experienced statistically significant increases in corrections spending in the aftermath of the court orders are all Southern and that in contrast only one of the five states experiencing no per capita increase in spending is Southern. Thus with the sole exception of Florida, there is a division by region. This prominence of the South is, I believe, the most significant finding in Taggart's study.

Historically, prison administration in the South has been different from that in the rest of the nation (McKelvey, 1977; Carleton, 1971). In the post-Civil War era prisons in many Southern states were consciously modeled on the plantation system, and indeed it was during this period that prisoners were described as "slaves of the state" (Ruffin v. Commonwealth, 62 Va. 790 (1871)). The most distinguishing characteristics of the plantation model were self-sufficiency and dependence on agriculture. The term "plantation" is more than a metaphor; it is a literal description. Southern prisons were run as plantations with convict labor replacing slave labor. Some in fact were privately owned or privately held on long-term leases and were run to make a profit. In a variation of this system, at times groups of convicts were leased to landowners for agricultural labor. Throughout the late nineteenth century and until the mid-twentieth century, a series of scandals and resulting reforms led to the steady demise of private prisons and the convict lease system. Despite this, the ideals of self-sufficiency and profit persisted even after the states had assumed full responsibility for the custody of convicts. Under such regimes, state-run institutions kept costs low by providing minimal services, requiring inmates to work at no or low pay, and using inmates as guards. It was these conditions and the abuses they spawned, which are so well documented in the testimony of witnesses and the opinions of trial court judges in the cases Taggart cites, that the Southern courts sought to change.

Courts in Ohio, New York, Rhode Island, and elsewhere also

6 It would be interesting to compare spending in the 5 Southern states with increases with spending in the 40 states not included in Taggart's study. The hypothesis I elaborate in the text suggests that the rate of spending in the 5 Southern states might be especially salient if the rate of spending in nonSouthern cases either remained constant as shown in the non-Southern states in his sample or decreased. During a period that included a moderate recession, such differences would further underscore the impact of the courts on the Southern prisons. It would also be interesting to determine if per capita spending in the South began to approach national averages; this would suggest another indication of the existence of a court-imposed national norm for prison administration. 
found that penal institutions were failing to meet constitutional standards by not supplying adequate services, cell space, and welltrained guards. But in the South, the courts did much more: They rejected a model, an entire way of thinking about prisons that for some had been a moral vision of what prison and imprisonment were all about. The rejection was total; it repudiated a longstanding and deeply engrained approach to prisons and replaced it with an alternative model, one that was in line with the dominant view of corrections officials and organizations across the nation.

Some early Northern prisons also operated under an ideal of profit or self-sufficiency. These systems, however, were never so fully entrenched or so well organized as the post-Civil War plantation models, and they began to disappear by the mid-nineteenth century. And of course the Southern plantation model and the conditions it fostered had been challenged by reformers long before the federal courts became involved. The emergence of a national corrections profession in the early twentieth century and the rise of the National Bureau of Prisons in mid-century both led many reformers in the South to reject the plantation model and to embrace modern penology, which at least in theory was the dominant view within the profession. Still, well into the 1960 s and 1970s Southern prisons remained different (McKelvey, 1977). A residual of the plantation model led state legislatures in the South to resist the "expensive luxury" of using tax funds to operate prisons. Southern prison reformers worked with varying degrees of success to overcome this resistance. One state in which the reformers had considerable success was Florida, where under the leadership of long-time Commissioner of Corrections Louie Wainwright the state modernized its prisons and brought them into line with emerging professional-and national-norms. ${ }^{7}$ There were reform efforts in other Southern states as well, although they were not as strong or successful as those in Florida. Reformers in these other states had to wait for the civil rights movement and the school desegregation cases to benefit from the searching scrutiny of other institutions by the federal judiciary that followed in their wake.

By the 1970s, the South's plantation model had become socially unacceptable. In the decisions whose budgetary impacts are examined by Taggart, the courts categorically rejected the self-imposed constraint of self-sufficiency, which had been used to justify such features of the plantation model as forced labor, the use of

7 For instance, the Florida Department of Corrections has been involved in the process of securing national accreditation of its prisons since the late 1960s. It was the first corrections department to complete the Self-Evaluation Project of the American Correctional Association. I am indebted to Thomas Blomberg of Florida State University and Linda Dees of the Florida Department of Corrections for supplying me with material on the recent history of the Florida Department of Corrections. 
convicts as guards, arbitrary discipline, the withholding of food, and the failure to supply medical treatment. Just as in the 1950 s and 1960s the federal courts had played a major role in articulating the unacceptability of another residue to plantation society-racial segregation-in the 1970 s they played a major role in rejecting one more feature of this society-the South's distinctive prison policies.

The general outlines of the history and impact of this prison reform movement are well known, but Taggart's study contributes new information about its scope and impact. It shows that most of the early cases were in the South and that among all the prison conditions cases in the nation at the time, those in the South led to the most significant budgetary increases. The article also demonstrates that the federal courts in these cases did more than sear moral consciences. They also forced the states to spend more money.

This massive judicial intervention has important implications not only for prisons but also for the concept of federalism. 8 These prison conditions cases constituted a categorical rejection of federalism as it applies to one traditional state function-prison administration. Federal deference to states in this area gave way to a single national model of prisons as federal judges in Louisiana, Alabama, Arkansas, Mississippi, Oklahoma, and elsewhere adopted the norms of national correctional associations and the National Bureau of Prisons, groups to whom the courts turned when searching for guidance. In short, judicial intervention in prisons represents the rejection of both the independent norms and standards and the tolerance of diversity and variation that had flourished under a regime of prison-administration federalism and that more generally is the presumed raison d'etre of federalism. The magnitude of this transformation is suggested by Taggart's findings that highlight the concentration of activity in the South and indicate that the greatest financial impact of these cases was in the South.

\section{CONCLUSION}

My assessment of the significance of these early prison conditions cases is thus at odds with Taggart's conclusion that they have had only limited impact. Nevertheless, my interpretation is consistent with his findings. He found that Southern states were the focus of litigation in a disproportionate number of cases and that it was in these states that the federal courts had their greatest budgetary impact. I interpret this to mean that the federal courts have had a significant impact on the prisons and jails in this region. They have altered the vision and often the guiding principles of corrections officials and have helped re-shape the structure and or-

8 The implications of court orders for federalism are examined in Feeley and Rubin (1988). 
ganization of jails and prisons. But Taggart's data suggest that the courts in the South have done more and that the new model they have imposed has been accompanied by substantial increases in expenditures. This is no mean achievement for a section of the country where for years officials had rejected as a matter of principle the "expensive luxury" of using state funds to house prisoners and where "all deliberate speed" once meant a snail's pace. And for students of federalism, the court orders and subsequent expenditures represent still one more arena in which national norms have displaced long-held state norms.

\section{REFERENCES}

BERGER, Raoul (1977) Government by Judiciary: The Transformation of the Fourteenth Amendment. Cambridge: Harvard University Press.

BICKEL, Alexander (1962) The Least Dangerous Branch. Indianapolis: Bobbs Merrill.

CARLETON, Mark T. (1971) Politics and Punishment: A History of the Louisiana State Penal System. Baton Rouge: Louisiana State University Press.

CHILTON, Bradley (1988) "Guthrie v. Evans: Civil Rights, Prison Reform and Institutional Reform Legislation." Ph.D. Dissertation, Department of Political Science, University of Georgia, Athens.

FEELEY, Malcolm M., and Roger HANSON (forthcoming) "The Impact of Jail and Prison Condition Litigation: A Review Essay," in John J. DiIulio, Jr. (ed.), Courts, Corrections and the Constitution. New York: Oxford University Press.

FEELEY, Malcolm M., and Edward RUBIN (1988) "Federal-State Relations and Prison Administration." Presented at the Third Annual Seminar on Federalism, Berkeley (November 5).

FLETCHER, William (1982) "The Discretionary Constitution: Institutional Remedies and Judicial Legitimacy," 92 Yale Law Journal 635.

FRUG, Gerald (1978) "The Judicial Power of the Purse," 126 University of Pennsylvania Law Review 715.

FULLER, Lon ([1957] 1978) "The Forms and Limits of Adjudication," 92 Harvard Law Review 352.

GLAZER, Nathan (1978) "Should Judges Administer Social Services?" 50 The Public Interest 64.

- (1975) "Towards an Imperial Judiciary?" 41 The Public Interest 104.

HARRIMAN, Linda, and Jeffrey D. STRAUSSMAN (1983) "Do Judges Determine Budget Decisions? Federal Court Decisions on Prison Reform and State Spending for Corrections," 43 Public Administration Review 343.

HARRIS, M. Kay, and Dudley P. SPILLER (1976) After Decision: Implementation of Judicial Decrees in Correctional Settings. Washington, DC: American Bar Association.

HOROWITZ, Donald L. (1977) The Courts and Social Policy. Washington, DC: Brookings Institution.

McKELVEY, Blake (1977) American Prisons: A History of Good Intentions. Montclair, NJ: Patterson-Smith.

MISHKIN, Paul (1978) "Federal Courts as State Reformers," 35 Washington and Lee Law Review 949.

TAGGART, William A. (1989) "Redefining the Power of the Federal Judiciary: The Impact of Court-Ordered Prison Reform on State Expenditures for Corrections," 23 Law \& Society Review 241.

WILDAVSKY, Aaron (1975) Budgeting: A Comparative Theory of Budgetary Processes. Boston: Little, Brown.

YARBROUGH, Tinsley (1987) Judge Frank Johnson and Human Rights in Alabama. University: University of Alabama Press. 


\section{CASES CITED}

Guthrie v. Evans, C.A. No. 73-3068 (S.D. Ga. 1979).

Holt v. Sarver, 300 F. Supp. 825 (E.D. Ark. 1969).

Pugh v. Locke, 406 F. Supp. 318 (M.D. Ala. 1976).

Ruffin v. Commonwealth, 62 Va. 790 (1871). 